\title{
Functional relationships between plasmids and their significance for metabolism and symbiotic performance of Rhizobium leguminosarum bv. trifolii
}

\author{
Grażyna Stasiak • Andrzej Mazur • Jerzy Wielbo • \\ Małgorzata Marczak • Kamil Żebracki • Piotr Koper • \\ Anna Skorupska
}

Received: 25 February 2014 / Revised: 11 April 2014 / Accepted: 30 April 2014 / Published online: 17 May 2014

(C) The Author(s) 2014. This article is published with open access at Springerlink.com

\begin{abstract}
Rhizobium leguminosarum bv. trifolii TA1 (RtTA1) is a soil bacterium establishing a highly specific symbiotic relationship with clover, which is based on the exchange of molecular signals between the host plant and the microsymbiont. The RtTA1 genome is large and multipartite, composed of a chromosome and four plasmids, which comprise approximately $65 \%$ and $35 \%$ of the total genome, respectively. Extrachromosomal replicons were previously shown to confer significant metabolic versatility to bacteria, which is important for their adaptation in the soil and nodulation competitiveness. To investigate the contribution of individual RtTA1 plasmids to the overall cell phenotype, metabolic properties and symbiotic performance, a transposonbased elimination strategy was employed. RtTA1 derivatives cured of pRleTA1b or pRleTA1d and deleted in pRleTA1a were obtained. In contrast to the in silico predictions of pRleTA1b and pRleTA1d, which were described as chromid-like replicons, both appeared to be completely curable. On the other hand, for pRleTA1a (symbiotic plasmid) and pRleTA1c, which were proposed to be unessential for RtTA1 viability, it was not possible to eliminate them at all (pRleTA1c) or entirely (pRleTA1a). Analyses of the phenotypic traits of the RtTA1 derivatives obtained revealed the functional significance of individual plasmids and their
\end{abstract}

Electronic supplementary material The online version of this article (doi:10.1007/s13353-014-0220-2) contains supplementary material, which is available to authorized users.

G. Stasiak · A. Mazur $(\bowtie) \cdot J$. Wielbo $\cdot$ M. Marczak $\cdot$ K. Żebracki $\cdot$ P. Koper $\cdot$ A. Skorupska

Department of Genetics and Microbiology, Maria-Curie Skłodowska University, 19 Akademicka St., 20-033 Lublin, Poland

e-mail: mazur@hektor.umcs.lublin.pl indispensability for growth, certain metabolic pathways, production of surface polysaccharides, autoaggregation, biofilm formation, motility and symbiotic performance. Moreover, the results allow us to suggest broad functional cooperation among the plasmids in shaping the phenotypic properties and symbiotic capabilities of rhizobia.

Keywords Rhizobium · Megaplasmids · Symbiosis · Metabolism $\cdot$ Plasmid curing

\section{Introduction}

Rhizobium leguminosarum bv. trifolii ( $R l t)$ is a soil bacterium establishing a symbiotic relationship with clover, Trifolium spp. and inducing the formation of root nodules on the host plant, in which bacteria differentiate into nitrogen-fixing bacteroids. Inside the nodules, atmospheric nitrogen is converted into ammonia and used by the plant as a nitrogen source. The interaction between rhizobia and leguminous plants shows a high degree of specificity, and successful infection of the roots is based on the exchange of molecular signals between the host plant and the microsymbiont (Dénarié et al. 1996; Long 1996; Jones et al. 2007). The specificity of the interaction between symbiotic partners is mediated largely by the Nod factor (NF), a substituted lipochitooligosaccharide molecule synthesised by the action of rhizobial nodulation (nod) genes, usually located on one of the plasmids (then called a symbiotic plasmid, pSym) or on the chromosome as symbiotic islands (Long 1996; Masson-Boivin et al. 2009). The NF elicits a series of physiological and developmental responses in the host plants, leading to nodule organogenesis (Perret et al. 2000). Chemical modifications of the NF further determine 
the host range (Dénarié et al. 1996). Besides the pSym, other parts of the rhizobial genome, especially non-symbiotic plasmids, may influence the symbiotic performance of bacteria by encoding additional factors such as proteins and cell surface polysaccharides that affect competitiveness and nitrogen fixation (Skorupska et al. 2006; Wielbo et al. 2007, 2010; LópezGuerrero et al. 2012; Sorroche et al. 2012).

Challenging environments, such as soil, in which resources are scarce and living conditions fluctuant, are frequently dominated by bacterial species with large and complex genomes. Rhizobial genomes, especially in the R. leguminosarum species, are large and multipartite, composed of a chromosome (core genome) and plasmids (accessory genome); the latter may comprise up to 35-45\% of the total genome (González et al. 2006; Young et al. 2006; Mazur et al. 2011b). In contrast to chromosomes, plasmids are considered as usually poorly conserved, flexible and heterogeneous in size and gene content. Variations in the location of chromosomal and extrachromosomal genes can be observed even in small rhizobial populations (Crossman et al. 2008; Mazur et al. 2011b; López-Guerrero et al. 2012). Some of the rhizobial extrachromosomal replicons referred to as chromids are characterised by a plasmid-type replication system but differ from plasmids in their GC content and codon usage, which are similar to those of the chromosome. Chromids were also distinguished on the basis of the presence of some genetic elements essential for growth under all conditions, which makes them impossible to be eliminated from the parental strains (Harrison et al. 2010; Landeta et al. 2011). On the other hand, plasmids are considered dispensable for growth and survival in natural habitats; these plasmids can be eliminated from the cells and are recognised as "recently" recruited, e.g. by horizontal DNA transfer (Petersen et al. 2013). Recently, the elimination of replicons designated as chromids on the basis of in silico analyses has been reported (Cheng et al. 2007). Petersen et al. (2013) modified the definition of chromids and proposed that replicons prone to elimination but indispensable for the survival in natural habitats should be regarded as essential "sensu lato", whereas those which cannot be eliminated because of the gene content belonging to the minimal essential gene set (Glass et al. 2006) should be regarded as chromids "sensu stricto".

It was shown that extrachromosomal replicons conferred significant metabolic versatility to rhizobia, which is important for their adaptation in the soil and nodulation competitiveness (Wielbo et al. 2007, 2010; Mazur et al. 2013). Up to now, several factors that contribute to rhizosphere colonisation and nodulation, such as motility and chemotaxis (Yost et al. 1998), metabolism of carbon and energy sources (Baldani et al. 1992; Oresnik et al. 1998; Yost et al. 2004, 2006; Guerreiro et al. 1998; Ormeño-Orrillo et al. 2008; Ramachandran et al. 2011; Ding et al. 2012), bacteriocin production (Hirsch et al. 1980; Oresnik et al. 1999; Venter et al. 2001), synthesis of vitamins (Miranda-Ríos et al. 1997; Villaseñor et al. 2011) and production of cell surface polysaccharides (Brom et al. 1992, 2000; García-de los Santos and Brom 1997; Skorupska et al. 2006), have been identified to be localised in plasmids in Rhizobium spp. (López-Guerrero et al. 2012; Mazur and Koper 2012, for a review). Besides the contribution of individual plasmids to the adaptive potential of rhizobia, their interactions also seem to be important. For example, the symbiotic capability of $R$. etli CFN42 was shown to be determined by genes located on pSym, but genes such as lps or fix also required for effective symbiosis are located on other plasmids, and for the mobilisation of plasmid pRet $42 \mathrm{~d}$ (pSym), a conjugative plasmid pRet42a is essential (Brom et al. 2000). Despite extensive research in the field, data concerning how the accessory genome itself and functional relationships between extrachromosomal replicons shape the phenotype and metabolism of the bacterial cell are still scarce.

The genome of $R$. leguminosarum bv. trifolii TA1 (RtTA1) is composed of five replicons: a chromosome and four megaplasmids (pRleTA1a-pRleTA1d), ranging in size from 476 to $808 \mathrm{~kb}$ (Król et al. 2008; Mazur et al. 2011a). The plasmids have been characterised as RepABC-type replicons, and two of them, i.e. pRleTA $1 \mathrm{~b}$ and pRleTAld, were predicted to be chromid-like replicons on the basis of their GC content and codon usage (Mazur et al. 2011a, b). The smallest plasmid, containing genes determining the ability to establish a nitrogen-fixing symbiosis, was identified as pSym (Król et al. 2008). Besides the repA, герB and rерC replication/ partition genes, only a small number of markers of individual RtTA1 plasmids was identified and sequenced (Król et al. 2008; Mazur et al. 2011a, b).

The aim of this work was to investigate the contribution of individual RtTA1 plasmids to the overall phenotype, metabolism and symbiotic performance, employing the elimination approach. A transposon-based strategy combined with a direct selection for plasmid loss was employed (Hynes et al. 1989; Brom et al. 1992). RtTA1 derivatives cured of or deleted in three individual plasmids have been obtained. Despite many attempts, curing of the entire pRleTA1c and pRleTAla plasmids was unsuccessful. Important phenotypic traits of the plasmid-cured or -deleted strains, i.e. growth kinetics, metabolic capabilities, autoaggregation, motility, biofilm formation, production of surface polysaccharides and symbiotic performance, were established and revealed some functional relationships between the RtTA1 plasmids.

\section{Materials and methods}

Bacterial strains and growth conditions

The bacterial strains and plasmids used in this work are listed in Table 1. Rhizobium strains were grown in 79CA (Vincent 
Table 1 Bacterial strains and plasmids used in this study

\begin{tabular}{|c|c|c|}
\hline Strain or plasmid & Relevant characteristic & Source or reference \\
\hline R. leguminosarum bv. trifolii & TA1, wild type, $\mathrm{Sm}^{\mathrm{r}}$, Rif & Chakravorty et al. (1982) \\
\hline R. leguminosarum bv. viciae & $3841, \mathrm{Sm}^{\mathrm{r}}$ & Young et al. (2006) \\
\hline RtTA101, RtTA105 & TA1 cured of pRleTA1d $\left(\mathrm{pd}^{-}\right)$ & This work \\
\hline RtTA102 & TA1 cured of pRleTA1b $\left(\mathrm{pb}^{-}\right)$ & This work \\
\hline RtTA106 & $\begin{array}{l}\text { TA1 deleted in pRleTA1a }(\mathrm{pa} \Delta) \text {, the size of residual pRleTA1a } \\
\text { was estimated at about } 300 \mathrm{~kb}\end{array}$ & This work \\
\hline RtTA107 & $\begin{array}{l}\text { TA1 deleted in pRleTA1a }(\mathrm{pa} \Delta) \text {, the size of residual pRleTA1a } \\
\text { was estimated at about } 400 \mathrm{~kb}\end{array}$ & This work \\
\hline RtTA109 & $\begin{array}{l}\text { TA1 deleted in pRleTA1a }(\mathrm{pa} \Delta) \text {, the size of residual pRleTA1a } \\
\text { was estimated at about } 350 \mathrm{~kb}\end{array}$ & This work \\
\hline Escherichia coli & S17-1, 294 RP4-2-Tc::Mu::Tn7 integrated into chromosome & Simon et al. (1983) \\
\hline pMH1701 & $\mathrm{Tn} 5-\mathrm{B} 12 \mathrm{~S}\left(\operatorname{sac} B, \mathrm{Mob}^{+}\right), \mathrm{Amp}^{\mathrm{r}}, \mathrm{Tc}^{\mathrm{r}}, \mathrm{Nm}^{\mathrm{r}}$ & Hynes et al. (1989) \\
\hline pJQ118 & Tn5-M8S $\left(\operatorname{sacB}, \mathrm{Mob}^{+}\right), \mathrm{Amp}^{\mathrm{r}}, \mathrm{Tc}^{\mathrm{r}}, \mathrm{Gm}^{\mathrm{r}}$ & Quandt et al. (2004) \\
\hline
\end{tabular}

1970), tryptone yeast (TY) or M1 media (Sambrook et al. 1989) at $28^{\circ} \mathrm{C}$ for 2-3 days. Escherichia coli strains were grown in Luria-Bertani (LB) medium at $37{ }^{\circ} \mathrm{C}$. Antibiotics were used at the following concentrations $\left(\mu \mathrm{g} \mathrm{ml}^{-1}\right)$ : ampicillin (Ap) 100-200, chloramphenicol (Cm) 30, gentamicin (Gm) 15, kanamycin (Km) 40, rifampicin (Rf) 40, streptomycin (Sm) 200-300 and tetracycline (Tc) 10. To select for plasmid loss, the media were supplemented with $5 \%$ sucrose.

Bacterial mating and screening for plasmid loss

Bacterial mating experiments were performed as described by Simon et al. (1983). Briefly, an E. coli S17-1 donor strain harbouring pMH1701 or pJQ118 plasmids (Hynes et al. 1989; Quandt et al. 2004) was grown to the early exponential phase in LB liquid medium with appropriate antibiotics, washed twice with sterile water and resuspended in water. The RtTA1 recipient strain was grown in 79CA to the late exponential phase and mixed with the donor strain at a ratio of 1:2. The mating mixture $(100 \mu \mathrm{l})$ was loaded onto a Millipore filter (0.45 $\mu \mathrm{m}$ pore size), placed on 79CA agar and incubated overnight at $28{ }^{\circ} \mathrm{C}$. The bacteria were then rinsed out from the filter with 79CA and selected on 79CA agar plates with kanamycin (pMH1701) or gentamicin (pJQ118) and rifampicin (for the donor counter selection). Cultures derived from single colonies of transconjugants were grown in liquid 79CA for $14-17 \mathrm{~h}$ at $28^{\circ} \mathrm{C}$ and plated in dilutions on TY with $5 \%$ sucrose. Colonies appearing on TY with sucrose were screened for the content of plasmids using the method of Eckhardt (1978).

\section{DNA methods}

Standard techniques were used for DNA labelling, Southern hybridisation and agarose gel electrophoresis (Sambrook et al.
1989). DNA probes for Southern hybridisation were obtained by polymerase chain reaction (PCR) amplification with RtTA1 genomic DNA as a template and appropriate primers. Primers and probes used in the study were described previously by Mazur et al. (2011b). Hybridisation probes were labelled with the non-radioactive DIG DNA Labeling and Detection Kit (Roche). Hybridisations were performed at high stringency at $42{ }^{\circ} \mathrm{C}$ using $50 \%$ formamide in prehybridisation solutions.

\section{Plasmid analyses}

For the analyses of the plasmid content of RtTA1 derivatives, the Eckhardt (1978) and pulsed-field gel electrophoresis (PFGE) techniques were used. PFGE was performed using the contour-clamped homogenous electric field mode with the Bio-Rad system (model CHEF-DR III). DNA samples were separated in $0.9 \%$ agarose gels in $0.5 \times \mathrm{TBE}$ buffer at $14{ }^{\circ} \mathrm{C}$, with switch times of $30-85 \mathrm{~s}$, angle $120^{\circ}$ and voltage gradient $6 \mathrm{~V} / \mathrm{cm}$ for $22 \mathrm{~h}$. The sizes of deleted derivatives of the RtTA1 plasmids were estimated using $R$. leguminosarum bv. viciae strain 3841 (Young et al. 2006) as a standard for replicon size.

\section{Growth kinetics testing}

Plasmid-cured or -deleted derivatives of RtTA1 were grown with shaking $(150 \mathrm{rpm})$ in $79 \mathrm{CA}$ medium for $48 \mathrm{~h}$. Afterwards, the cells were washed in sterile water, suspended to $\mathrm{OD}_{550} 0.01$ in TY, 79CA and M1 medium [the latter was supplemented with a vitamin mixture according to Brown and Dilworth (1975)], and various carbon sources to $1 \%$. The $\mathrm{OD}_{550}$ of the cultures grown with shaking at $28{ }^{\circ} \mathrm{C}$ was monitored at regular time intervals $(24 \mathrm{~h})$ up to $72 \mathrm{~h}$. The measurements were done in triplicate. 
Analysis of the utilisation of carbon and energy sources

The Biolog GN2 MicroPlate (Biolog, Hayward, CA, USA) test (Bochner 2009) was conducted according to the manufacturer's instructions. Briefly, rhizobia grown overnight at $28{ }^{\circ} \mathrm{C}$ on TY agar medium were collected and washed with sterile water. Next, the pellet was diluted in water to an initial $\mathrm{OD}_{550}$ of 0.1 (approximately $10^{8}$ cells ml $^{-1}$ ) and $150 \mu \mathrm{l}$ of the rhizobial suspension was inoculated into each well of the GN2 microplate. The plates were incubated for $72 \mathrm{~h}$ at $28^{\circ} \mathrm{C}$ and colour development (absorbance at 590 and $750 \mathrm{~nm}$ ) in the wells was recorded using a Benchmark Plus microplate reader (Bio-Rad Laboratories, USA). The conversion of colourless tetrazolium violet to a purple-coloured compound meant a normal process of respiration (positive phenotype), whereas, when the phenotype was negative, the wells remained colourless. The optical density values of the Biolog microplate wells were corrected using background colour developed in the control well.

\section{EPS isolation}

Bacteria were grown in $79 \mathrm{CA}$ with $1 \%$ glycerol at $28{ }^{\circ} \mathrm{C}$ for $48 \mathrm{~h}$. EPS was precipitated from 1-ml culture supernatants with three volumes of $96 \%$ ethanol. The precipitate was collected by centrifugation, dried, resolved in water and submitted for the total carbohydrate analysis according to Loewus (1952). The total sugar content was calculated as glucose equivalents and was the result of four independent replicas.

\section{Analysis of autoaggregation}

Autoaggregation of bacteria was measured as described by Sorroche et al. (2012). Bacteria were grown at $28^{\circ} \mathrm{C}$ for $24 \mathrm{~h}$, diluted 100-fold in TY medium and incubated for $48 \mathrm{~h}$. Afterwards, $5 \mathrm{ml}$ of bacterial cultures were transferred to new tubes, measured for the absorbance at $600 \mathrm{~nm}\left(\mathrm{~A}_{0}\right)$ and then incubated at $4{ }^{\circ} \mathrm{C}$ for $24 \mathrm{~h}$ without agitation. Next, $0.2 \mathrm{ml}$ of the upper suspension was transferred to microplate wells and $\mathrm{OD}_{600}\left(\mathrm{~A}_{\mathrm{t}}\right)$ was measured in eight independent experiments. The autoaggregation percentage was expressed as follows: $1-\left(\mathrm{A}_{\mathrm{t}} / \mathrm{A}_{0}\right) \times 100$ (Sorroche et al. 2012).

Motility and biofilm formation assay

The motility assay was conducted in $0.3 \% \mathrm{M} 1$ agar medium with glycerol. A 5 - $\mu$ l culture grown in M1 medium at $28{ }^{\circ} \mathrm{C}$ for $24 \mathrm{~h}$ to an $\mathrm{OD}_{600}$ of 0.4 was stabbed into plates with $\mathrm{TY}$ medium. The plates were incubated at $28{ }^{\circ} \mathrm{C}$ for 3 days, and bacterial growth from the point of inoculation was measured. The motility assay was done in triplicate. Biofilm formation was assessed as described previously by Fujishige et al. (2006) and Sorroche et al. (2012). Briefly, rhizobial strains were grown in TY medium at $28{ }^{\circ} \mathrm{C}$ for $48 \mathrm{~h}$. The cultures were diluted to an $\mathrm{OD}_{600}$ of 0.1 in TY, inoculated into 96-well microtitre plates in $100-\mu l$ aliquots and incubated with agitation $(100 \mathrm{rpm})$ at $28^{\circ} \mathrm{C}$ for $24 \mathrm{~h}$. Next, bacterial growth was assessed by measuring the $\mathrm{OD}_{600}$. The planktonic cells were gently removed, stained for 15 min with $180 \mu 10.1 \%$ crystal violet and then rinsed three times with water. Biofilm formation was quantified by the addition of $150 \mu \mathrm{l}$ of $95 \%$ ethanol and measurement of the absorbance at $560 \mathrm{~nm}$ was done in a microplate reader MicroElisa Autoreader. The experiment was performed in triplicate.

\section{Plant tests}

Seeds of red clover (T. pratense L. cv. Rozeta) were surfacesterilised and germinated on nitrogen-free medium, as described earlier (Vincent 1970). Two-day-old clover seedlings were planted in sterile nitrogen-free slants (one per tube) and allowed to grow for 4 days before being inoculated with $0.2 \mathrm{ml}$ of Rlt cell suspension at an approximate density of $1.0 \times 10^{9}$ cells $/ \mathrm{ml}$. The plants were grown in a greenhouse under natural light supplemented with an artificial light regime (14/10 h light/dark). After 5 weeks, the plants were harvested and fresh mass of shoots/roots and nodule formation were examined. Twenty clover plants were used for each strain. To assess the stability of the plasmid-cured RtTA1 derivatives, the rhizobia were isolated from a few nodules and their plasmid content was examined.

\section{Statistical analyses}

The results of RtTA1 derivatives: growth kinetics, EPS production, plant tests, as well as autoaggregation, motility and biofilm formation assays, were submitted for statistical analyses, which were performed with STATISTICA software, using one-way analysis of variance (ANOVA) and the Tukey test at a significance level of $p<0.05$.

\section{Results}

RtTA1 plasmid elimination

The RtTA1 laboratory strain contains four extrachromosomal replicons, designated pRleTA1d, pRleTA1c, pRleTA1b and pRleTA1a (Fig. 1), with approximate molecular sizes of 808 , 653, 603 and $476 \mathrm{~kb}$, respectively. To assess the impact of particular plasmids on the RtTA1 phenotype, symbiotic capabilities and metabolism, an elimination experiment was undertaken using the transposon-based $(\operatorname{Tn} 5 \mathrm{sacB})$ method 


\begin{tabular}{|c|c|c|c|c|c|c|c|c|c|c|c|c|c|c|c|c|c|c|c|c|c|c|c|c|c|c|c|c|c|}
\hline \multirow{2}{*}{\multicolumn{2}{|c|}{$\begin{array}{c}\text { Strains } \\
\text { Replicons }\end{array}$}} & \multicolumn{4}{|c|}{ RtTA1 } & \multicolumn{4}{|c|}{ RtTA101/pd $^{-}$} & \multicolumn{4}{|c|}{ RtTA105/pd- } & \multicolumn{4}{|c|}{ RtTA102/pb $^{-}$} & \multicolumn{4}{|c|}{ RtTA106/pa $\triangle$} & \multicolumn{4}{|c|}{ RtTA107/pa $\Delta$} & \multicolumn{4}{|c|}{ RtTA109/pa $\triangle$} \\
\hline & & d & c & b & a & d & c & b & a & d & c & b & a & d & c & b & a & d & c & $\mathbf{b}$ & a* & d & c & b & $a^{*}$ & d & c & b & $a^{*}$ \\
\hline \multirow{4}{*}{ 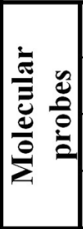 } & repC/d & + & & & & - & & & & - & & & & + & & & & + & & & & + & & & & + & & & \\
\hline & rep $C / b$ & & & + & & & & + & & & & + & & & & - & & & & + & & & & + & & & & + & \\
\hline & $r e p C / a$ & & & & + & & & & + & & & & + & & & & + & & & & + & & & & + & & & & + \\
\hline & nodA & & & & + & & & & + & & & & + & & & & + & & & & - & & & & - & & & & - \\
\hline \multicolumn{2}{|c|}{$\begin{array}{l}\text { Plasmid } \\
\text { profiles }\end{array}$} & \multicolumn{3}{|c|}{$\begin{array}{ll}\mathrm{d} & \\
\mathrm{c} \\
\mathrm{b} \\
\mathrm{b}\end{array}$} & & \multicolumn{4}{|c|}{5} & \multicolumn{4}{|c|}{$-4=$} & \multicolumn{4}{|c|}{$=5$} & \multicolumn{4}{|c|}{5} & \multicolumn{4}{|c|}{$=8$} & \multicolumn{4}{|c|}{5} \\
\hline
\end{tabular}

Fig. 1 Genetic characteristic of $R$. leguminosarum bv. trifolii TA1 and its plasmid-cured or-deleted derivatives. Plasmid profiles of all strains were obtained with agarose gel electrophoresis using the Eckhardt lysis procedure and are shown at the bottom of the table. Particular replicons of RtTA1 and its derivatives are marked with letters a, b, c and d, which refer to pRleTA1a, pRleTA1b, pRleTA1c and pRleTA1d plasmids, respectively. The strains shown are: RtTA1, the wild type, RtTA101 and RtTA105 (pRleTA1d-cured), RtTA102 (pRleTA1b-cured), and RtTA106, RtTA107 and RtTA109 (pRleTA1a-deleted). The asterisks show the positions of pRleTA1a deletion derivatives. The replicons of the strains were PFGE separated and probed with $r e p C$ genes specific for individual plasmids and $\operatorname{nod} A$ specific for the symbiotic plasmid; "+" means positive hybridisation and "-" negative hybridisation. The column with pRleTA1c was shaded grey as no hybridisation with probes specific for this plasmid was performed

Symbiotic properties of RtTA1 derivatives cured or deleted in individual plasmids

pRleTAla has been previously identified as a symbiotic plasmid containing a nod-fix region responsible for nodulation and nitrogen fixation (Król et al. 2008; Mazur et al. 2011b). The RtTA106, RtTA107 and RtTA109 strains with deletions in pRleTA1a and displaying negative hybridisation with the nodA probe lost the ability to nodulate clover, confirming the indispensability of pRleTAla for the symbiotic interaction. Fresh masses of plant shoots inoculated with these derivatives were significantly lower (average $20.24 \mathrm{mg} /$ plant, Tukey test $p<0.05)$ than of clover plants infected with the RtTA1 wild type ( $25.45 \mathrm{mg} /$ plant) (Fig. 2).

The elimination of pRleTA1b did not affect the nodulation ability of the RtTA102 derivative: its symbiotic performance (nodule number 12.3/plant, average fresh shoot mass $28.3 \mathrm{mg} /$ plant) was even higher than that of the RtTA1 wild type (nodule number 7.3/plant).

The plants inoculated with RtTA101 and RtTA105 cured of pRleTA1d showed significantly lower fresh masses of shoots (average $20.5 \mathrm{mg} / \mathrm{plant}$, in comparison to $25.45 \mathrm{mg} /$ plant for wild type) and a nodule number similar to that of the wild type (average 8 nodules/plant). However, in comparison to RtTA1, their nodulation kinetics was different, as the nodules appeared on clover roots with delay (not shown). Furthermore, the weight as well as the yellowish colour of clover shoots inoculated with the pRleTA1d-eliminated strains resembled the ones inoculated with the pSym-deleted derivatives, allowing a conclusion that the symbiotic phenotype of these strains was $\mathrm{Nod}^{+} \mathrm{Fix}^{-}$.

These results not only indicated the indispensability of the pRleTA1a plasmid for effective symbiosis but also pointed out specific for individual replicons, are shown in Fig. 1. 


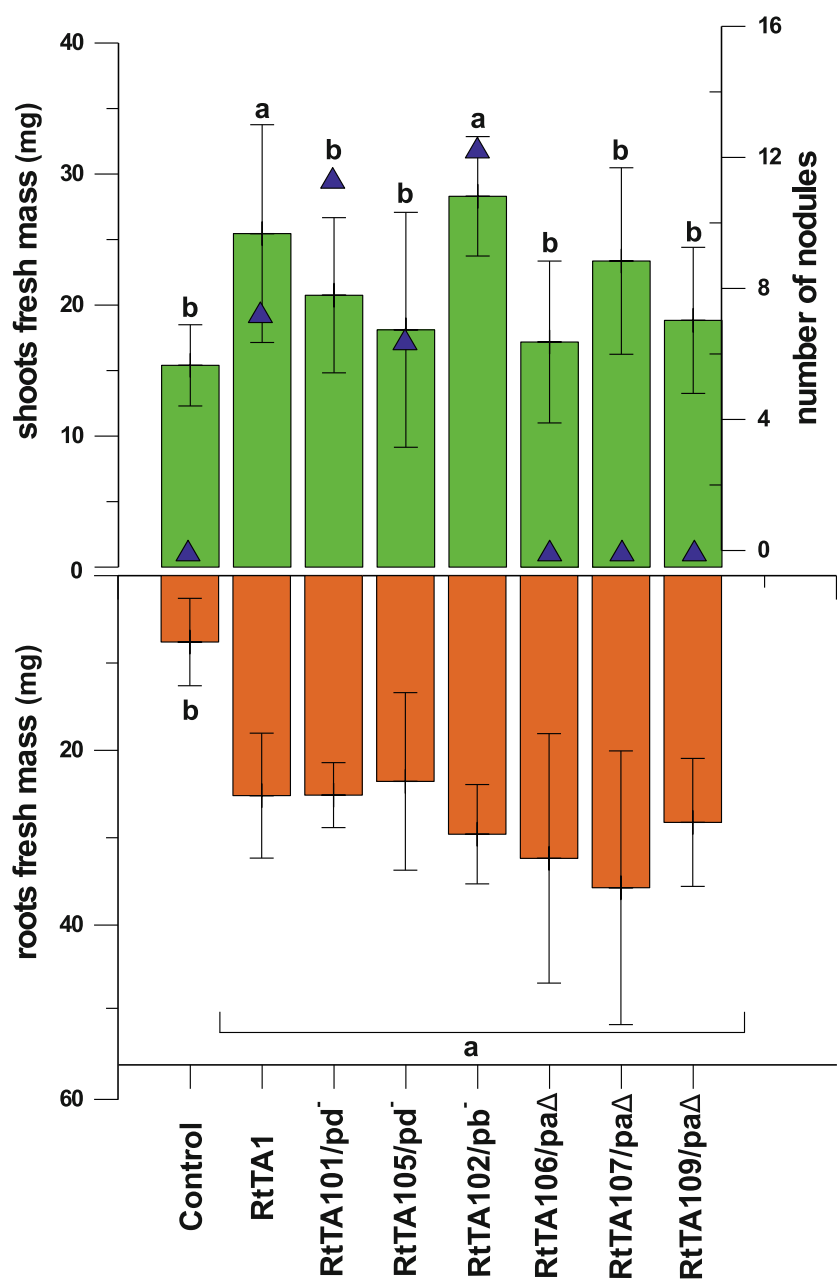

Fig. 2 Symbiotic capabilities of RtTA1 derivatives cured or deleted in individual plasmids inoculated on clover plants (T. pratense). The triangles indicate the number of nodules/plant, the green bars indicate shoot masses of plants (mg/plant) and the orange bars indicate fresh mass of roots (mg/plant). The bars labelled with various letters represent shoot and root mass values which are significantly different at $p<0.05$ and the extended bars represent the standard deviation

the functional relationship between the pRleTAla and pRleTA1d replicons in the symbiotic interaction with clover.

Growth kinetics of RtTA1 plasmid-cured or -deleted derivatives

All RtTA1 derivatives cured or deleted in individual plasmids grew weaker in comparison to RtTA1 in complete media. In 79CA, the growth of the pRleTA1d-cured (RtTA101 and RtTA105) and pRleTA1b-cured (RtTA102) strains was apparently slower in relation to the wild type strain (Fig. 3). The RtTA106, RtTA107 and RtTA109 derivatives deleted in pRleTA1a grew faster than those cured of pRleTA1d or pRleTA1b and only slightly slower than RtTA1 (Fig. 3); however, only the growth of RtTA101 and RtTA102 differed significantly from the other strains, including the wild type (Fig. 3). The differences in the growth of the strains in TY medium were less apparent, but, still, RtTA102 grew substantially more weakly than the other strains (data not shown). All RtTA1 derivatives were able to grow in $\mathrm{M} 1-\mathrm{NH}_{4}$ minimal medium supplemented with vitamins and mannose as a sole carbon source. In comparison to the other strains, RtTA102 displayed weaker growth in $\mathrm{M} 1-\mathrm{NH}_{4}$ with glycerol and it did not grow in M1 with rhamnose as a sole carbon source (data not shown).

Taken together, it may be concluded that pRleTA1d and pRleTAlb plasmids, but not pSym, substantially affect the RtTA1 growth, which emphasises their importance for cell metabolism.

Determination of EPS production, autoaggregation and biofilm formation by the RtTA1 derivatives

To further characterise the impact of RtTA1 plasmids on the cell phenotype, we focused on the bacterial extracellular components, which contribute significantly to the rhizobial capabilities important for saprophytic and symbiotic performance. It has been shown that the quality and quantity of surface polysaccharides, particularly exopolysaccharides (EPSs) and lipopolysaccharides (LPSs), produced by rhizobia may influence both their autoaggregation and biofilm formation (Rinaudi and González 2009; Sorroche et al. 2010, 2012). Rhizobial cell-to-surface interaction leading to the formation of biofilm plays a crucial role in root hair infection during symbiosis (Bogino et al. 2013).

In $R$. leguminosarum bv. trifolii RtTA1, the main gene cluster required for EPS synthesis, i.e. Pss-I, is localised on the chromosome. Other regions plausibly involved in EPS and LPS production were also identified in the RtTA1 genome, with one of them, namely Pss-III, localised in the pRleTA1b plasmid (Król et al. 2007). The exopolysaccharide production by RtTA1 derivatives cured of or deleted in individual plasmids was measured. All RtTA1 derivatives produced slightly higher amounts of EPS in comparison to the RtTA1 wild type (Fig. 4); however, only the amount of EPS observed in the RtTA109 strain deleted in pRleTA1a differed significantly (Fig. 4). Together, the results suggested the existence of a complex regulatory network of EPS synthesis consisting of genes located on different plasmids and especially on pSym.

Symbiotic bacteria may develop on plant roots as microcolonies, bacterial aggregates or biofilms (Morris and Monier 2003). Therefore, we analysed the autoaggregation and biofilm formation capabilities of RtTA1 derivatives. Bacterial autoaggregation is a process whereby bacteria physically interact with each other and settle to the bottom in a static liquid suspension (Sorroche et al. 2010, 2012). The level of autoaggregation of RtTA1 derivatives resulting in their sedimentation on the bottom of tubes during growth in 79CA static liquid cultures was measured. Almost all derivatives differed significantly from the wild type; however, only 


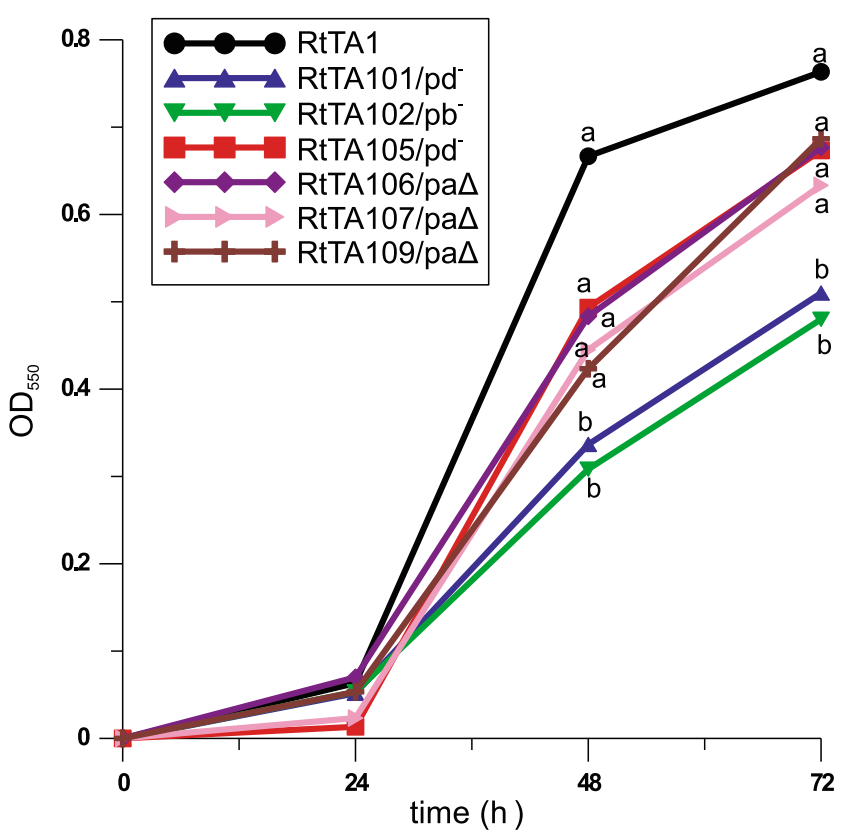

Fig. 3 The growth rate of RtTA1 and its plasmid-cured or -deleted derivatives in 79CA medium with $1 \%$ mannitol. The $\mathrm{OD}_{550}$ of the cultures grown with shaking was monitored at regular time intervals up to $72 \mathrm{~h}$. The $\mathrm{OD}_{550}$ values of the cultures measured after 48 and $72 \mathrm{~h}$ labelled with the various letters are significantly different at $p<0.05$. Standard deviation bars were omitted in order to facilitate chart analysis

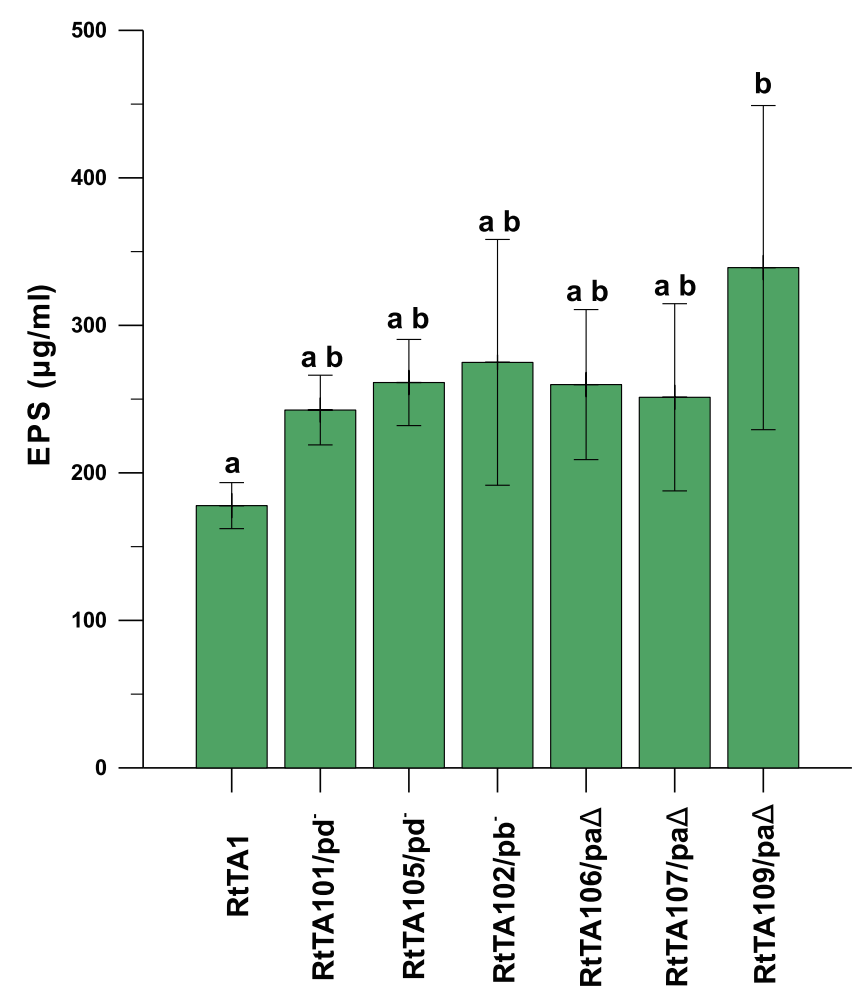

Fig. 4 EPS production by RtTA1 plasmid-cured or -deleted derivatives as measured after cultivation in 79CA medium with $1 \%$ glycerol. The total sugars content was calculated in glucose equivalents $(\mu \mathrm{g} / \mathrm{ml})$. The green bars labelled with the various letters represent EPS values which are significantly different at $p<0.05$ and the extended bars represent the standard deviation the RtTA102 (pRleTA1b-cured) strain showed substantially increased autoaggregation when compared to RtTA1 (34.5\% RtTA102 vs. $23.6 \%$ RtTA1) (Fig. 5). With the exception of RtTA102, no obvious relation between individual plasmid elimination and cell self-aggregation was noticed.

In Sinorhizobium meliloti, a positive correlation between autoaggregation and biofilm formation was found, indicating that both processes depend on the same physical adhesive forces (Sorroche et al. 2012). The biofilm formation by the RtTA1 plasmid-cured or -deleted derivatives was examined by the classical crystal violet (CV) method employing microtitre plastic plates (Fujishige et al. 2006) (Fig. 6). In contrast to self-aggregation, the highest biofilm formation was noticed for the RtTA1 wild type $\left(\mathrm{OD}_{560} / \mathrm{OD}_{600}\right.$ ratio 5.8), as well as for the RtTA101 and RtTA105 strains cured of pRleTA1d $\left(\mathrm{OD}_{560} / \mathrm{OD}_{600}\right.$ ratios 5.2 and 4.7 , respectively). The pRleTA1a deletion in strains RtTA106, RtTA107 and RtTA109 resulted in a significant $(p<0.05)$ reduction of the biofilm amount $\left(\mathrm{OD}_{560} / \mathrm{OD}_{600}\right.$ ratios 3.85, 3.67 and 3.8, respectively). A substantially diminished amount of biofilm (statistically important difference, $p<0.05$ ) was also observed for RtTA102 $\left(\mathrm{OD}_{560} / \mathrm{OD}_{600}\right.$ ratio 3.3), but no correlation between self-aggregation of the cells and biofilm formation was determined. It may be concluded that the presence of both pRleTAla and pRleTA1b is important for biofilm formation, while pRleTA1d plays an insignificant role in this process.

Bacterial motility is one of the critical factors for the establishment of symbiosis under natural soil conditions (Morris and González 2009; Tambalo et al. 2010). In S. meliloti, the regulatory proteins MucR, ExoR and ExpR, which play essential roles in EPS synthesis, also seem to be engaged in motility, indicating that the regulation of these two processes may be coupled (Hoang et al. 2008). From among the derivatives studied, the pRleTAld-cured strains were negative in the motility test (Fig. 7). The swimming zones of RtTA101 and RtTA105 after growth on 79CA semisolid medium for $72 \mathrm{~h}$ were significantly smaller, $1.6 \mathrm{~mm}$ in comparison to $7.38 \mathrm{~mm}$ for RtTA1, while for the other tested derivatives, it ranged from 7.5 to $8.25 \mathrm{~mm}$ (Fig. 7). This shows that mainly pRleTA1d-located genes are essential for RtTA1 motility.

The impact of RtTA1 plasmids on the metabolic profile of the cells

To assess the metabolic differences between the RtTA1 wild type and its derivatives with changed plasmid content, Biolog GN2 microplates containing 96 carbon and nitrogen sources were used (Supplementary Table S1). To simplify the analysis, the substrates in GN2 microplates were divided into sugars (polysaccharides, oligosaccharides, monosaccharides, comprising $34.4 \%$ of the tested compounds), modified sugar acids, carboxylic acids (29.2\%), amino acids (21.9\%), 
Fig. 5 Autoaggregation of RtTA1 plasmid-cured or -deleted derivatives. a Quantitative estimation of autoaggregation of strains cultured in 79CA; the autoaggregation is expressed in \% according to the following equation: $1-\left(A_{t} / A_{0}\right) \times 100$, where $\mathrm{A}_{0}$ stands for $\mathrm{OD}_{600}$ measured before the non-agitation period and $A_{t}$ is the $O_{600}$ value after $24 \mathrm{~h}$ without agitation. The green bars labelled with the various letters represent autoaggregation values which are significantly different at $p<0.05$ and the extended bars represent the standard deviation. b Example of growth of the wild type RtTA1 and RtTA102 strains cured of pRITA1b in 79CA medium

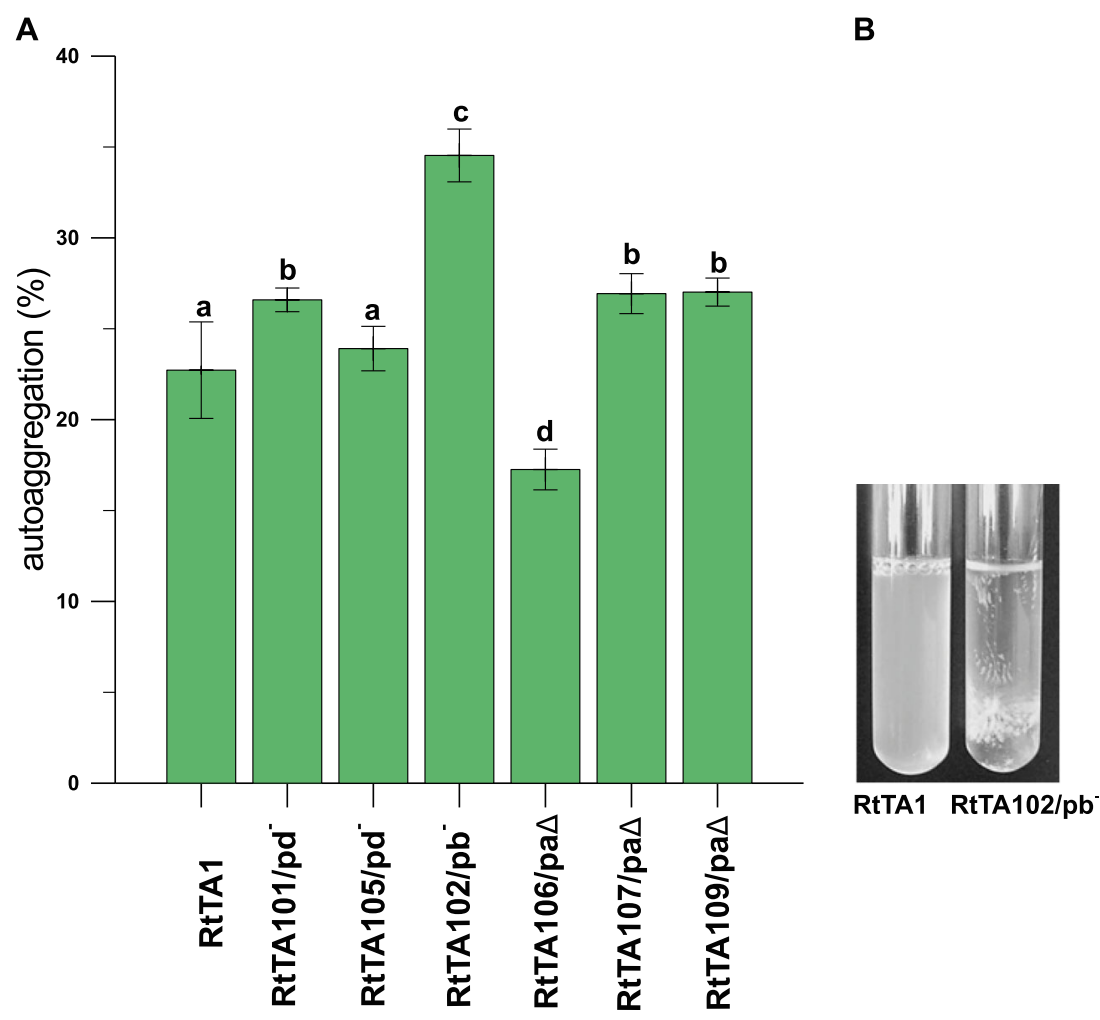

nitrogen bases and other compounds (15.5\%) (Table 2). In general, the loss or deletion of any of the plasmids resulted in changes in the metabolic capabilities (Table 2). In the group of sugar substrates, the lack of pRleTA1d in RtTA101 and RtTA105 correlated with deficiency in the use of i-erythritol (sugar alcohol) as a metabolic substrate. RtTA101 and RtTA105 were also not able to use D-psicose, a carbon-3 epimer of D-fructose (Supplementary Table S1). L-rhamnose (6-deoxyhexose), xylitol and D-sorbitol (sugar alcohols) were not used by the RtTA102 strain cured of pRleTA1b. The inability to use gentiobiose, a disaccharide composed of two units of D-glucose, was observed for all RtTA1 derivatives (Supplementary Table S1).

Noticeable changes in the metabolic profiles were observed in the group of tested carboxylic acids. Firstly, a correlation between pRleTA1d elimination and deficiency in using cisaconitic acid was found. Secondly, pRleTA1b elimination or pRleTA1a deletion were correlated with the inability to use $\gamma$ hydroxybutyric acid. The most spectacular differences in the number of substrates metabolised by the studied strains were observed in the amino acid group, especially in the case of the pRleTAlb-cured derivative, which was defective in using Laspartic acid, L-glutamic acid, L-histidine, L-ornithine and Lproline. The pRleTA1d-cured strain did not use L-histidine and L-aspartic acid as substrates. All RtTA1 derivatives under study lost the ability to use L-ornithine and L-proline (Supplementary Table S1).

\section{Discussion}

The extrachromosomal replicons of $R$. leguminosarum bv. trifolii TA1 constitute approximately $35.5 \%$ of the total genome. It can be assumed that such a huge amount of accessory genetic information must significantly contribute to the cell phenotype and metabolism. In this work, we succeeded in eliminating individual plasmids pRleTA1b and pRleTA1d and obtained derivatives with partial deletions in pSym. Only pRleTA1c elimination or deletion was unsuccessful. The failed attempts to eliminate the pRleTAlc and pRleTA1a replicons entirely suggest that they are essential for RtTA1 viability under the conditions studied. This was an unexpected result, as the other RtTA1 replicons, i.e. pRleTA $1 b$ and pRleTA1d, were previously described as chromid-like, based on in silico analyses and their membership to the same incompatibility group with well-defined chromid replicons of $R$. leguminosarum bv. viciae and $R$. etli (Harrison et al. 2010; Mazur et al. 2011a). In turn, on the basis of partial sequence analyses, the pRleTA1c and pRleTA1a replicons were classified as plasmids - less adapted to the host genome and presumably unessential for strain viability (Mazur et al. 2011a).

The genome sequence of RtTA1 has been released only as draft assemblies, precluding precise localisation of important or essential genes in RtTA1 plasmids. Moreover, only a few RtTA1 extrachromosomal markers have been sequenced 


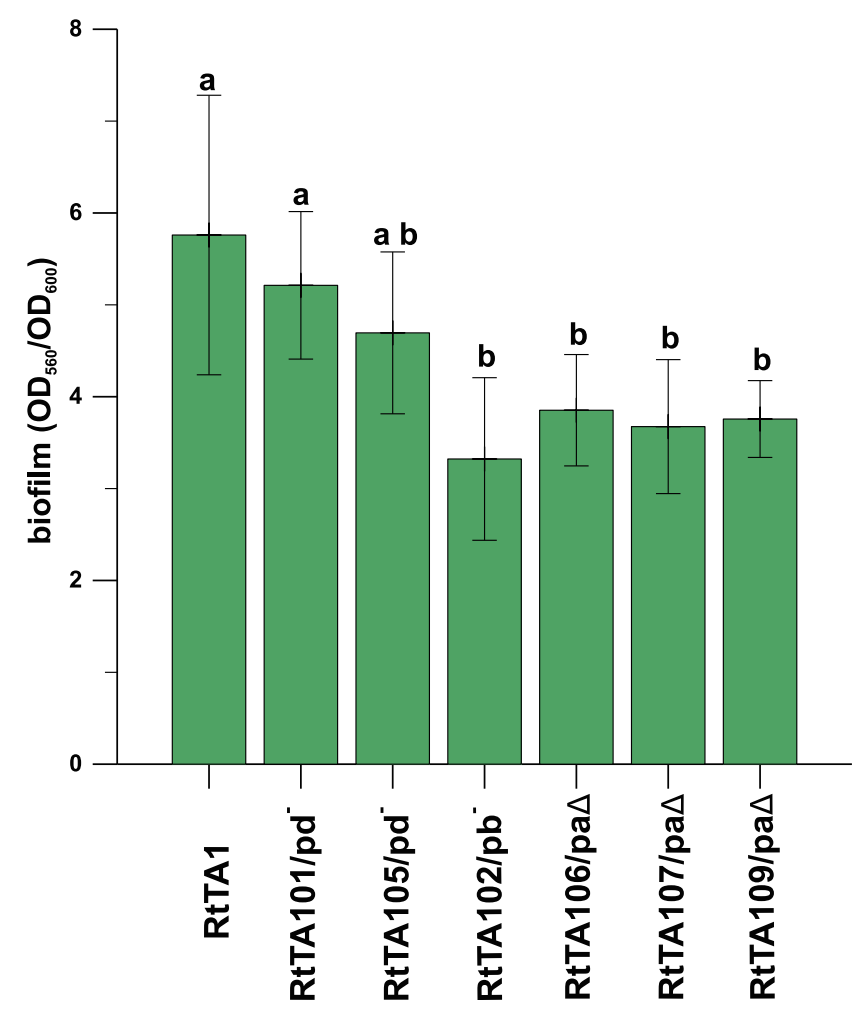

Fig. 6 Biofilm formation by the RtTA1 wild type strain and plasmidcured or-deleted derivatives as assessed by microtitre plate assay. Biofilm formation capabilities were examined after $24 \mathrm{~h}$ from inoculation by staining with crystal violet and expressed as the ratio of the amount of crystal violet solubilised by ethanol $\left(\mathrm{OD}_{560}\right)$ to the bacterial growth $\left(\mathrm{OD}_{550}\right)$. The experiment was performed in triplicate and averaged. The green bars labelled with the various letters represent biofilm amounts which are significantly different at $p<0.05$ and the extended bars represent the standard deviation

(Król et al. 2008; Mazur et al. 2011b), allowing only speculation about the importance of the pRleTA1c replicon for cell viability. In this replicon, besides specific rep $A B C$ replication/ partition genes, lps $\beta 2$ encoding a dTDP-glucose 4,6-dehydrogenase involved in the biosynthesis of O-antigen, ots $B$ encoding a phosphate-trehalose, tau $A$ encoding a taurine uptake protein and orfl4 encoding a flavin monooxygenase/ reductase protein have been mapped (Król et al. 2007; Mazur et al. 2011b). The homologues of lps $\beta 2$ have been previously described as plasmid located (lps $\beta 1-l p s \beta 2$ region in pRet42b) and involved in LPS synthesis in R. etli (Garcíade los Santos and Brom 1997) and R. leguminosarum bv. viciae (Carlson et al. 1995; Young et al. 2006). LPS is the
Table 2 Metabolic profiles of RtTA1 and its derivatives cured or deleted in plasmids, assayed on Biolog GN2 microplates. The metabolic substrates were divided into four groups. The number of substrates in each group and the number of substrates utilised by strains is shown

\begin{tabular}{|c|c|c|c|c|c|}
\hline & $\begin{array}{l}\text { Total } \\
\text { substrates }\end{array}$ & Sugars & Acids & $\begin{array}{l}\text { Amino } \\
\text { acids }\end{array}$ & Others \\
\hline No. of substrates in group & 95 & 35 & 28 & 23 & 9 \\
\hline Strain/genotype & \multicolumn{5}{|c|}{ No. of substrates utilised } \\
\hline RtTA1/wild type & 35 & 21 & 8 & 6 & 0 \\
\hline $\mathrm{RtTA} 101 / \mathrm{pd}^{-}$ & 27 & 19 & 6 & 2 & 0 \\
\hline $\mathrm{RtTA} 105 / \mathrm{pd}^{-}$ & 28 & 19 & 6 & 3 & 0 \\
\hline RtTA102/pb & 25 & 20 & 5 & 0 & 0 \\
\hline RtTA104/pa $\Delta$ & 29 & 18 & 7 & 4 & 0 \\
\hline RtTA106/pa $\Delta$ & 29 & 20 & 6 & 3 & 0 \\
\hline RtTA109/pa $\Delta$ & 31 & 21 & 6 & 4 & 0 \\
\hline
\end{tabular}

$\mathrm{pd}^{-}, \mathrm{pb}^{-}$: strains lacking plasmid; $\mathrm{pa} \Delta$ : partial deletion of plasmid $\mathrm{pSym}$

major structural component of the outer membrane of Gramnegative bacteria and the absence of the lps genes affects substantially bacterial growth. Thus, the lps $\beta 2$ gene encoding a hypothetical protein involved in the synthesis of 6-deoxy or dideoxy sugars, linking the O-antigen to the core oligosaccharide, could be a reasonable candidate for an essential gene in pRleTA1c, supporting its essentiality for bacterial growth. However, as demonstrated by Brom et al. (2000), pRet $42 \mathrm{~b}$ carrying lps $\beta 1-l p s \beta 2$ can be entirely eliminated from $R$. etli. To gain further insight into a presence of putative essential genes in pRleTA1c, a 255,620-bp-long contig of this plasmid (available in the GenBank draft genome database, accession no. AKIA01000012), comprising less than half of the plasmid size, was used as a query against the Database of Essential Genes (DEG) (Luo et al. 2013). Among the identified ORFs, those with similarity to proteins constituting hypothetical ABC-type transporters predominated. They may be presumably involved in the transport of peptides (both oligo- and dipeptide), amino acids, maltose/mannitol, iron, spermidine/ putrescine and sulphates. Moreover, putative ORFs with similarity to biotin carboxylase subunit and related to glycerol metabolism were found.

In the case of symbiotic plasmid pRleTA1a, which can be lost in other $R$. leguminosarum strains, only partially deleted derivatives were obtained for RtTA1. The result again suggested the presence of essential genes on this plasmid. A

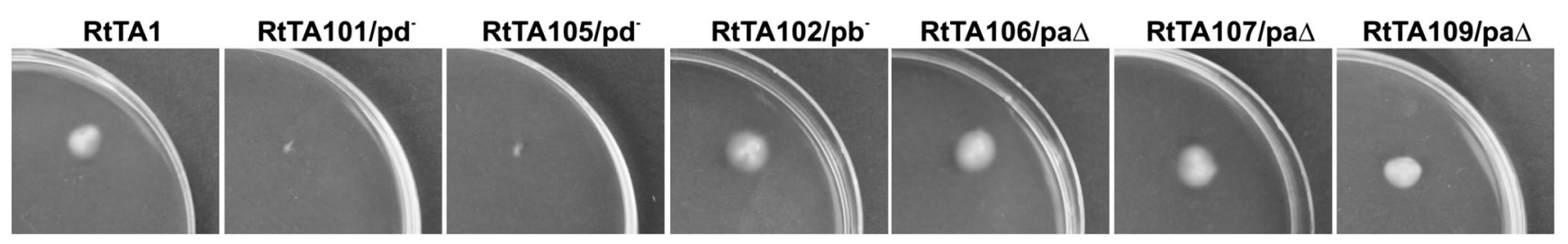

Fig. 7 Swimming motility of RtTA1 wild type strain and plasmid-cured or -deleted derivatives. Bacterial growth from the point of inoculation in M1 agar medium $(0.3 \%)$ was measured after 3 days 
similar approach was employed in the search for pRleTA1a putative essential genes. In a 136,237-bp contig of pSym (GenBank accession no. AKIA01000031), a large number of ORFs with sequence similarity to the putative transporters was identified (involved in the transport of calcium, zinc/cadmium/mercury/lead, copper, molybdate, glutamate/ aspartate). Furthermore, hypothetical osmolarity response regulator and two-component sensory transduction proteins were detected. In the analysed contig, the fusA gene encoding hypothetical elongation factor $\mathrm{G}$ (proteins of this family can be involved in the elongation and ribosome recycling during protein synthesis) and the $f t s E$ gene encoding a putative cell division ATP-binding protein/septation component were found. Genes related to septum formation were also identified in pRet42e, which cannot be entirely eliminated from $R$. etli (Landeta et al. 2011). Similarly to pRet $42 \mathrm{e}$, genes involved in thiamine biosynthesis are located in pRleTA1a (Mazur et al. 2011b). Concluding, in silico analyses of pRleTA1c and pRleTA1a replicons' partial sequences did not unambiguously prove the essential genes content. However, in the context of the discussion presented by Petersen et al. (2013), pRleTA1c and pRleTAla could be defined as common plasmids that acquired some chromosomal sequences, e.g. via intragenomic recombination, while pRleTA1b and pRleTA1d are chromidlike (Mazur et al. 2011a) "sensu lato" that are curable and dispensable for survival under laboratory conditions. This implies that no chromids "sensu stricto" (Petersen et al. 2013), which are non-curable and essential for growth under all conditions, were identified in the RtTA1 genome. The completion of several rhizobial genome projects provided numerous pieces of evidence of such intragenomic recombination events, which lead to the location of essential genes on plasmids. The pSymB megaplasmid of S. meliloti 1021 contains genes encoding tRNA ${ }^{\text {arg }}$ and eng $A$ (GTPase, likely to be involved in ribosome biogenesis) (diCenzo et al. 2013). The homologous genes of closely related $S$. fredii NGR234 are located on the chromosome, which strongly suggests that they could be translocated from the chromosome to the progenitor of pSymB in an ancestor common to both bacterial species. Other examples of core genes located on plasmids are $p a n C B$ genes responsible for pantothenate biosynthesis in pRet $42 \mathrm{f}$, the largest replicon of $R$. etli CFN42 (a second copy of panB is also located in pRet42e) (Villaseñor et al. 2011). Pantothenate is considered relevant for central metabolism, and the plasmid location of pan genes may be explained by their intragenomic transfer from the chromosome, because pan $C B$ orthologues are chromosomally located in $R$. leguminosarum bv. viciae and trifolii and other Rhizobiales (Villaseñor et al. 2011).

We demonstrated that both pRleTA1a (pSym) and pRleTA1d (non-symbiotic plasmid) are essential for RtTA1 symbiosis with clover. The pRleTAld-cured strains induced an even higher number of nodules on clover than the wild type, but did not fix nitrogen. This result not only demonstrated the indispensability of pRleTA1d for successful symbiosis but also pointed out the interactions between the plasmids within the RtTA1 cell, which contribute to important bacterial capabilities. In the pioneer studies with $R$. etli derivatives cured of individual plasmids, Brom et al. (1992) showed that, in addition to pSym (pRet42d), a second, nonsymbiotic plasmid (pRet42b) was also indispensable for nodule formation due to the presence of the sequences required for LPS biosynthesis. The homologous lps $\beta$ region in RtTA1 is located in the pRleTA1c non-curable plasmid, whose role in symbiosis remains unknown, rather than in pRleTA1d. However, the presence of some other symbiotically important sequences cannot be precluded in the case of such a large replicon as pRleTA1d. There are several other proofs for the impact of non-symbiotic plasmids on rhizobial interaction with legume plants. In R. leguminosarum bv. viciae VF39, besides pSym, two other plasmids carry genes necessary for symbiosis, including lps genes (Hynes and McGregor 1990). In R. leguminosarum bv. viciae 3841, the expression of several plasmid genes was induced in the pea rhizosphere; those genes were specifically located on conjugative, non-symbiotic pRL8JI and represented about $15 \%$ of the plasmid genes (Ramachandran et al. 2011).

Elimination of the plasmid from $R$. leguminosarum bv. trifolii may affect both saprophytic lifestyle as well as growth in the clover rhizosphere in a natural bacterial population (Moënne-Loccoz and Weaver 1995a, b). This may be a result of the plasmid location of some catabolic genes, such as those involved in the utilisation of rhamnose (Oresnik et al. 1998), erythritol (Yost et al. 2006; Geddes et al. 2010) and glycerol (Ding et al. 2012). Ding et al. (2012) showed that mutants in glycerol transport and catabolism genes located in pRleVF39c of $R$. leguminosarum bv. viciae VF39 were not only unable to use glycerol but were also deficient in competitiveness for the nodulation of peas (Ding et al. 2012). In our studies, the metabolic consequences of RtTA1 curing of the largest pRleTA1d were considerable: it not only impaired the ability for nitrogen fixation but also affected the growth kinetics in the complete media. Similarly, curing RtTA1 of the pRleTA1b resulted in deficiency in using several amino acids as metabolic substrates and affected strain growth in the complete media. On the contrary, the growth of RtTA1 Nod derivatives that lost a substantial part of pSym was comparable to the wild type in complete and minimal media. Similarly, mutations in common nod genes did not affect the growth of $S$. meliloti (Fujishige et al. 2008). Furthermore, curing of the pRme2011 symbiotic plasmid of $S$. meliloti (Oresnik et al. 2000) or sequential deletions covering the entire pSymA of $S$. meliloti 1021 (Yurgel et al. 2013) did not affect the free-living growth of bacteria; however, it entailed some non-essential defects in cell catabolism. Consequently, we have demonstrated in the Biolog GN2 test that the metabolic capabilities of the RtTA106, RtTA107 and RtTA109 strains deleted in pSym 
differed from those of the wild type: the strains did not metabolise amino acids (L-proline, L-ornithine) and acids (succinic acid methyl ester, $\gamma$-hydroxybutyric acid). The ability to utilise amino and organic acids is an important attribute of $R$. leguminosarum competitiveness in the rhizosphere. We found in previous studies that the most competitive rhizobial strains were those capable of using a broad range of amino and organic acids (Wielbo et al. 2007, 2010). Mutants unable to use L-homoserine (which is the component of pea root exudate) as the sole carbon source were affected in the competitive nodulation of pea and lentil (Vanderlinde et al. 2014). Furthermore, strong up-regulation of some plasmid-encoded genes of R. leguminosarum bv. viciae 384 in the pea rhizosphere was demonstrated by a microarray-based study (Ramachandran et al. 2011).

The RtTA1 derivatives deleted in pSym exhibited substantially reduced biofilm formation abilities (on average $66 \%$ of the wild type). The development of biofilm requires the expression of numerous genes implicated in various cell processes, like signalling, stress responses, motility and the synthesis of structures responsible for cell attachment. Our result is consistent with the observation made by Fujishige et al. (2008): in S. meliloti, products of common nodABCD genes, responsible for core NF synthesis, were also required for rhizobial cell-to-surface adhesion. The core NF structure is similar to chitosan, which promotes cell adhesion by making the microbial surface more hydrophobic (Fujishige et al. 2008). The smallest amount of biofilm (57\%) was formed by a strain cured of pRITA1b, indicating that genes located on this plasmid play a role in biofilm formation, together with the ones from pSym. On the contrary, the largest plasmid-cured derivatives produced $80-88 \%$ biofilm compared to the RtTA1 wild type, demonstrating an insignificant role of this plasmid in biofilm formation. The biofilm analyses once again revealed the interrelation among the plasmids residing in one cell.

Autoaggregation is yet another common phenotype of bacteria that have a strong tendency toward adhesive interactions among cells. This is manifested by clumping in liquid cultures (Sorroche et al. 2012) and several surface components, such as LPS, outer membrane or pili, have been described as adhesion conducive (Sorroche et al. 2010). Autoaggregation could reflect a survival strategy of bacteria under stress environmental conditions. From among the RtTA1 derivatives, RtTA102 cured of the pRleTA1b plasmid displayed the strongest autoaggregation tendency in relation to the wild type. Taking into account the fact that RtTA102 is severely defective in overall metabolism, the suggestion about the influence of stress conditions on aggregation seems to be supported.

A majority of the hitherto identified genes required for EPS synthesis have been mapped on chromosomes of R. leguminosarum and R. etli (González et al. 2006; Young et al. 2006; Mazur et al. 2011b), but some putative EPS/LPS synthesis genes were also found to be scattered among plasmids (Król et al. 2007). Loss of the pRleTA1b plasmid with a Pss-III region did not influence significantly the level of EPS synthesis in RtTA102, demonstrating an irrelevant role of this plasmid in EPS biosynthesis. Nevertheless, the generally increased production of EPS by all the RtTA1 derivatives studied suggested a complex regulatory network of EPS synthesis, presumably comprising genes located in different plasmids.

In several studies, a relation between the production of bacterial polysaccharides and motility has been shown. Motility is required for the chemotactic movement of bacteria towards the compounds released by its host, while exopolysaccharides are needed for bacterial attachment to the root or for invasion of the infection thread (Bahlawane et al. 2008; Morris and González 2009). The swarming ability of $S$. meliloti Rm2011 was shown to depend on a functional ExpR/Sin quorum-sensing system and the production of both flagella and EPS (Hoang et al. 2008). In R. leguminosarum bv. viciae, six flagellin genes $(f l a A / B / C / D / H / G)$ were found on the chromosome: $f l a A / B / C / D$ are located within the major chemotaxis and the motility cluster, while flaE was mapped on plasmid pRle11JI (Tambalo et al. 2010). In this work, the pRleTA1d-cured derivatives are non-motile, indicating a possibility of the regulation of putative flagellin gene expression by the plasmid-located loci. However, further experimentation is needed to confirm the correlation between motility and the plasmid gene(s).

Overall, our approach, whose aim was to eliminate individual plasmids from $R$. leguminosarum bv. trifolii, revealed their functional significance and indispensability in some metabolic pathways, symbiotic interaction with host plant, biofilm formation and potential survival in the soil. Equally important, the results suggested a broad relationship among the plasmids in shaping the symbiotic capabilities and cell phenotype.

Open Access This article is distributed under the terms of the Creative Commons Attribution License which permits any use, distribution, and reproduction in any medium, provided the original author(s) and the source are credited.

\section{References}

Bahlawane C, McIntosh M, Krol E, Becker A (2008) Sinorhizobium meliloti regulator MucR couples exopolysaccharide synthesis and motility. Mol Plant Microbe Interact 21:1498-1509

Baldani JI, Weaver RW, Hynes MF, Eardly BD (1992) Utilization of carbon substrates, electrophoretic enzyme patterns, and symbiotic performance of plasmid-cured clover rhizobia. Appl Environ Microbiol 58:2308-2314

Bochner BR (2009) Global phenotypic characterization of bacteria. FEMS Microbiol Rev 33:191-205 
Bogino PC, Oliva Mde L, Sorroche FG, Giordano W (2013) The role of bacterial biofilms and surface components in plant-bacterial associations. Int J Mol Sci 14:15838-15859

Brom S, García de los Santos A, Stepkowsky T, Flores M, Dávila G, Romero D et al (1992) Different plasmids of Rhizobium leguminosarum bv. phaseoli are required for optimal symbiotic performance. J Bacteriol 174:5183-5189

Brom S, García-de los Santos A, Cervantes L, Palacios R, Romero D (2000) In Rhizobium etli symbiotic plasmid transfer, nodulation competitivity and cellular growth require interaction among different replicons. Plasmid 44:34-43

Brown CM, Dilworth MJ (1975) Ammonia assimilation by Rhizobium cultures and bacteroids. J Gen Microbiol 86:39-48

Carlson RW, Reuhs B, Chen TB, Bhat UR, Noel KD (1995) Lipopolysaccharide core structures in Rhizobium etli and mutants deficient in O-antigen. J Biol Chem 270:11783-11788

Chakravorty AK, Zurkowski W, Shine J, Rolfe BG (1982) Symbiotic nitrogen fixation: molecular cloning of Rhizobium genes involved in exopolysaccharide synthesis and effective nodulation. J Mol Appl Genet 1:585-596

Cheng J, Sibley CD, Zaheer R, Finan TM (2007) A Sinorhizobium meliloti minE mutant has an altered morphology and exhibits defects in legume symbiosis. Microbiology 153:375-387

Crossman LC, Castillo-Ramírez S, McAnnula C, Lozano L, Vernikos GS, Acosta JL et al (2008) A common genomic framework for a diverse assembly of plasmids in the symbiotic nitrogen fixing bacteria. PLoS One 3:e2567

Dénarié J, Debellé F, Promé JC (1996) Rhizobium lipo-chitooligosaccharide nodulation factors: signaling molecules mediating recognition and morphogenesis. Annu Rev Biochem 65:503-535

diCenzo G, Milunovic B, Cheng J, Finan TM (2013) The tRNAarg gene and eng $A$ are essential genes on the $1.7-\mathrm{Mb}$ pSymB megaplasmid of Sinorhizobium meliloti and were translocated together from the chromosome in an ancestral strain. J Bacteriol 195:202-212

Ding H, Yip CB, Geddes BA, Oresnik IJ, Hynes MF (2012) Glycerol utilization by Rhizobium leguminosarum requires an $\mathrm{ABC}$ transporter and affects competition for nodulation. Microbiology 158:1369-1378

Eckhardt T (1978) A rapid method for the identification of plasmid desoxyribonucleic acid in bacteria. Plasmid 1:584-588

Fujishige NA, Kapadia NN, De Hoff PL, Hirsch AM (2006) Investigations of Rhizobium biofilm formation. FEMS Microbiol Ecol 56:195-206

Fujishige NA, Lum MR, De Hoff PL, Whitelegge JP, Faull KF, Hirsch AM (2008) Rhizobium common nod genes are required for biofilm formation. Mol Microbiol 67:504-515

García-de los Santos A, Brom S (1997) Characterization of two plasmidborne lps $\beta$ loci of Rhizobium etli required for lipopolysaccharide synthesis and for optimal interaction with plants. Mol Plant Microbe Interact 10:891-902

Geddes BA, Pickering BS, Poysti NJ, Collins H, Yudistira H, Oresnik IJ (2010) A locus necessary for the transport and catabolism of erythritol in Sinorhizobium meliloti. Microbiology 156:2970-2981

Glass JI, Assad-Garcia N, Alperovich N, Yooseph S, Lewis MR, Maruf $M$ et al (2006) Essential genes of a minimal bacterium. Proc Natl Acad Sci U S A 103:425-430

González V, Santamaria RI, Bustos S, Hernández-González I, MedranoSoto A, Moreno-Hagelsieb G, et al (2006) The partitioned Rhizobium etli genome: genetic and metabolic redundancy in seven interacting replicons. Proc Natl Acad Sci USA 103:3834-3839

Guerreiro N, Stepkowski T, Rolfe BG, Djordjevic MA (1998) Determination of plasmid-encoded functions in Rhizobium leguminosarum biovar trifolii using proteome analysis of plasmidcured derivatives. Electrophoresis 19:1972-1979

Harrison PW, Lower RP, Kim NK, Young JP (2010) Introducing the bacterial 'chromid': not a chromosome, not a plasmid. Trends Microbiol 18:141-148
Hirsch PR, Van Montagu M, Johnston AWB, Brewin NJ, Schell J (1980) Physical identification of bacteriocinogenic, nodulation and other plasmids in strains of Rhizobium leguminosarum. J Gen Microbiol 120:403-412

Hoang HH, Gurich N, González JE (2008) Regulation of motility by the ExpR/Sin quorum-sensing system in Sinorhizobium meliloti. J Bacteriol 190:861-871

Hynes MF, McGregor NF (1990) Two plasmids other than the nodulation plasmid are necessary for formation of nitrogen-fixing nodules by Rhizobium leguminosarum. Mol Microbiol 4:567-574

Hynes MF, Quandt J, O'Connell MP, Pühler A (1989) Direct selection for curing and deletion of Rhizobium plasmids using transposons carrying the Bacillus subtilis sacB gene. Gene 78:111-120

Jones KM, Kobayashi H, Davies BW, Taga ME, Walker GC (2007) How rhizobial symbionts invade plants: the Sinorhizobium-Medicago model. Nat Rev Microbiol 5:619-633

Król JE, Mazur A, Marczak M, Skorupska A (2007) Syntenic arrangements of the surface polysaccharide biosynthesis genes in Rhizobium leguminosarum. Genomics 89:237-247

Król JE, Mazur A, Marczak M, Skorupska A (2008) Application of physical and genetic map of Rhizobium leguminosarum bv. trifolii TA1 to comparison of three closely related rhizobial genomes. Mol Genet Genomics 279:107-121

Landeta C, Dávalos A, Cevallos MÁ, Geiger O, Brom S, Romero D (2011) Plasmids with a chromosome-like role in rhizobia. J Bacteriol 193:1317-1326

Loewus FA (1952) Improvement in anthrone method for determination of carbohydrates. Anal Chem 24:219

Long SR (1996) Rhizobium symbiosis: nod factors in perspective. Plant Cell 8:1885-1898

López-Guerrero MG, Ormeño-Orrillo E, Acosta JL, Mendoza-Vargas A, Rogel MA, Ramírez MA et al (2012) Rhizobial extrachromosomal replicon variability, stability and expression in natural niches. Plasmid 68:149-158

Luo H, Lin Y, Gao F, Zhang CT, Zhang R (2013) DEG 10, an update of the database of essential genes that includes both protein-coding genes and noncoding genomic elements. Nucleic Acids Res 42:D574-D580

Masson-Boivin C, Giraud E, Perret X, Batut J (2009) Establishing nitrogen-fixing symbiosis with legumes: how many rhizobium recipes? Trends Microbiol 17:458-466

Mazur A, Koper P (2012) Rhizobial plasmids - replication, structure and biological role. Cent Eur J Biol 7:571-586

Mazur A, Majewska B, Stasiak G, Wielbo J, Skorupska A (2011a) rep $A B C$-based replication systems of Rhizobium leguminosarum bv. trifolii TA1 plasmids: incompatibility and evolutionary analyses. Plasmid 66:53-66

Mazur A, Stasiak G, Wielbo J, Kubik-Komar A, Marek-Kozaczuk M, Skorupska A (2011b) Intragenomic diversity of Rhizobium leguminosarum bv. trifolii clover nodule isolates. BMC Microbiol $11: 123$

Mazur A, Stasiak G, Wielbo J, Koper P, Kubik-Komar A, Skorupska A (2013) Phenotype profiling of Rhizobium leguminosarum bv. trifolii clover nodule isolates reveal their both versatile and specialized metabolic capabilities. Arch Microbiol 195:255-267

Miranda-Ríos J, Morera C, Taboada H, Dávalos A, Encarnación S, Mora $\mathrm{J}$ et al (1997) Expression of thiamin biosynthetic genes (thiCOGE) and production of symbiotic terminal oxidase $c b b 3$ in Rhizobium etli. J Bacteriol 179:6887-6893

Moënne-Loccoz Y, Weaver RW (1995a) Plasmids influence growth of rhizobia in the rhizosphere of clover. Soil Biol Biochem 27:1001-1004

Moënne-Loccoz Y, Weaver RW (1995b) Plasmids and saprophytic growth of Rhizobium leguminosarum bv. trifolii W14-2 in soil. FEMS Microbiol Ecol 18:139-144

Morris J, González JE (2009) The novel genes emmABC are associated with exopolysaccharide production, motility, stress adaptation, and symbiosis in Sinorhizobium meliloti. J Bacteriol 191:5890-5900 
Morris CE, Monier JM (2003) The ecological significance of biofilm formation by plant-associated bacteria. Annu Rev Phytopathol 41: 429-453

Oresnik IJ, Pacarynuk LA, O'Brien SAP, Yost CK, Hynes MF (1998) Plasmid-encoded catabolic genes in Rhizobium leguminosarum bv. trifolii: evidence for a plant-inducible rhamnose locus involved in competition for nodulation. Mol Plant Microbe Interact 11:1175-1185

Oresnik IJ, Twelker S, Hynes MF (1999) Cloning and characterization of a Rhizobium leguminosarum gene encoding a bacteriocin with similarities to RTX toxins. Appl Environ Microbiol 65:2833-2840

Oresnik IJ, Liu SL, Yost CK, Hynes MF (2000) Megaplasmid pRme2011a of Sinorhizobium meliloti is not required for viability. J Bacteriol 182:3582-3586

Ormeño-Orrillo E, Rosenblueth M, Luyten E, Vanderleyden J, MartínezRomero E (2008) Mutations in lipopolysaccharide biosynthetic genes impair maize rhizosphere and root colonization of Rhizobium tropici CIAT899. Environ Microbiol 10:1271-1284

Perret X, Staehelin C, Broughton WJ (2000) Molecular basis of symbiotic promiscuity. Microbiol Mol Biol Rev 64:180-201

Petersen J, Frank O, Göker M, Pradella S (2013) Extrachromosomal, extraordinary and essential - the plasmids of the Roseobacter clade. Appl Microbiol Biotechnol 97:2805-2815

Quandt J, Clark RG, Venter AP, Clark SR, Twelker S, Hynes MF (2004) Modified RP4 and Tn5-Mob derivatives for facilitated manipulation of large plasmids in Gram-negative bacteria. Plasmid 52:1-12

Ramachandran VK, East AK, Karunakaran R, Downie JA, Poole PS (2011) Adaptation of Rhizobium leguminosarum to pea, alfalfa and sugar beet rhizospheres investigated by comparative transcriptomics. Genome Biol 12:R106

Rinaudi LV, González JE (2009) The low-molecular-weight fraction of exopolysaccharide II from Sinorhizobium meliloti is a crucial determinant of biofilm formation. J Bacteriol 191:7216-7224

Sambrook J, Fritsch EF, Maniatis T (1989) Molecular cloning: a laboratory manual, 2nd edn. Cold Spring Harbor Laboratory Press, New York

Simon R, Priefer U, Pühler A (1983) A broad host range mobilization system for in vivo genetic engineering: transposon mutagenesis in gram negative bacteria. Nat Biotechnol 1:784-791

Skorupska A, Janczarek M, Marczak M, Mazur A, Król J (2006) Rhizobial exopolysaccharides: genetic control and symbiotic functions. Microb Cell Fact 5:7

Sorroche FG, Rinaudi LV, Zorreguieta A, Giordano W (2010) EPS IIdependent autoaggregation of Sinorhizobium meliloti planktonic cells. Curr Microbiol 61:465-470
Sorroche FG, Spesia MB, Zorreguieta A, Giordano W (2012) A positive correlation between bacterial autoaggregation and biofilm formation in native Sinorhizobium meliloti isolates from Argentina. Appl Environ Microbiol 78:4092-4101

Tambalo DD, Bustard DE, Del Bel KL, Koval SF, Khan MF, Hynes MF (2010) Characterization and functional analysis of seven flagellin genes in Rhizobium leguminosarum bv. viciae. Characterization of R. leguminosarum flagellins. BMC Microbiol 10:219

Vanderlinde EM, Hynes MF, Yost CK (2014) Homoserine catabolism by Rhizobium leguminosarum bv. viciae 3841 requires a plasmid-borne gene cluster that also affects competitiveness for nodulation. Environ Microbiol 16:205-217

Venter AP, Twelker S, Oresnik IJ, Hynes MF (2001) Analysis of the genetic region encoding a novel rhizobiocin from Rhizobium leguminosarum bv. viciae strain 306. Can J Microbiol 47:495-502

Villaseñor T, Brom S, Dávalos A, Lozano L, Romero D, Los Santos AG (2011) Housekeeping genes essential for pantothenate biosynthesis are plasmid-encoded in Rhizobium etli and Rhizobium leguminosarum. BMC Microbiol 11:66

Vincent JM (1970) A manual for the practical study of root-nodule bacteria. Blackwell Scientific Publications, Oxford

Wielbo J, Marek-Kozaczuk M, Kubik-Komar A, Skorupska A (2007) Increased metabolic potential of Rhizobium spp. is associated with bacterial competitiveness. Can J Microbiol 53:957-967

Wielbo J, Marek-Kozaczuk M, Mazur A, Kubik-Komar A, Skorupska A (2010) Genetic and metabolic divergence within a Rhizobium leguminosarum bv. trifolii population recovered from clover nodules. Appl Environ Microbiol 76:4593-4600

Yost CK, Rochepeau P, Hynes MF (1998) Rhizobium leguminosarum contains a group of genes that appear to code for methyl-accepting chemotaxis proteins. Microbiology 144:1945-1956

Yost CK, Del Bel KL, Quandt J, Hynes MF (2004) Rhizobium leguminosarum methyl-accepting chemotaxis protein genes are down-regulated in the pea nodule. Arch Microbiol 182:505-513

Yost CK, Rath AM, Noel TC, Hynes MF (2006) Characterization of genes involved in erythritol catabolism in Rhizobium leguminosarum bv. viciae. Microbiology 152:2061-2074

Young JP, Crossman LC, Johnston AW, Thomson NR, Ghazoui ZF, Hull $\mathrm{KH}$ et al (2006) The genome of Rhizobium leguminosarum has recognizable core and accessory components. Genome Biol 7:R34

Yurgel SN, Mortimer MW, Rice JT, Humann JL, Kahn ML (2013) Directed construction and analysis of a Sinorhizobium meliloti pSymA deletion mutant library. Appl Environ Microbiol 79:2081-2087 